\title{
SCANNING ELECTRON MICROSCOPY OF CONIDIA OF TRICHODERMA STROMATICUM, A BIOCONTROL AGENT OF WITCHES' BROOM DISEASE OF COCOA
}

\author{
Itamar Soares de Melo ${ }^{1 *}$; Jane L. Faull ${ }^{2}$ \\ ${ }^{1}$ Embrapa, Centro Nacional de Pesquisa de Monitoramento e Avaliação de Impacto Ambiental, Jaguariúna, SP, Brasil; \\ ${ }^{2}$ Birkbeck College, London University, London, UK
}

Submitted: June 14, 2004; Returned to Authors: August 19, 2004; Approved: November 26, 2004

\section{SHORT COMMUNICATION}

\begin{abstract}
A field emission electron microscope (SEM) was used to study the conidia surface of Trichoderma stromaticum, a biocontrol of witches broom disease of cocoa. Surface features of conidia were difficult distinguish by light microscope. Conidia appeared to be verrugose and minutely roughened, but the nature of the roughening was not easy to discern. It was common to observe sheath-like structures that completely covered groups of conidia, and also details of wide cells that form the pustules.
\end{abstract}

Key words: Biological control, cocoa, Crinipellis pernisiosa, morphology of conidia

Conidia surface ornamentation and conidial matrix, as observed with the scanning electron microscopy, is significant in the taxonomy of Trichoderma species (8).

The Trichoderma species aggregates have been difficult to subdivide into biological species. Each aggregate represents a number of species $(1,12)$ and morphological characters that can reliably define biological species have not been identified. This type of classification is highly artificial and Domsch et al., (6) and Bissett (1) have revised partly the genus for useful system to differentiate among phenotypically similar species.

Species of the genus Trichoderma are ubiquitous active components of the soil microbiota and well known for their production of hydrolytic enzymes (11), antibiotics (5), heterologous proteins $(3,9)$ and as biocontrol agents against phytopathogens (4) and its current commercial use in some countries (10).

T. stromaticum sp. nov. (13), isolated from dry brooms of cocoa, has been used in the field to control the basidiomycete Crinipellis perniciosa. The antagonist acts preventing the basidioma formation. The new species belongs to Trichoderma sect. Pachybasium (1), with T. harzianum and T. virens representing the closest relations.

This paper presents results of scanning electron microscopy of conidial surface ornamentation of $T$. stromaticum.

Strain and culture methods. One strain of T. stromaticum, TVC, isolated from dead cocoa broom was provided by Dr. J. C. B. Costa of CEPEC / CEPLAC, Bahia State, Brazil. Cultures were maintained on $2 \%$ malt extract agar.

Material for SEM examination of conidial surfaces was obtained from cultures that were grown on 2\% MEA for 12 days at $26^{\circ} \mathrm{C}$, and grown under cool white fluorescent lamp with an alternating cycle of $12 \mathrm{~h}$ of light and $12 \mathrm{~h}$ of darkness.

Agar blocks were cut into small pieces with conidiating hyphae and fixed in $2 \%$ glutaraldehyde in $0.1 \mathrm{M}-\mathrm{NaPO}_{4}$ buffer and post-fixed in buffered $1 \% \mathrm{O}_{5} \mathrm{O}_{4}$ for $2 \mathrm{~h}$. The material was then dehydrated in an ethanol series $(10,25,40,60,75,85,95$, $100 \%$ ) with 15 min per change. The specimens were dried in a critical point drying apparatus and sputter-coated with gold and viewed using a field emission scanning electron microscope, Leo 982 (Zeiss + Leica).

*Corresponding author. Mailing address: Embrapa - Centro Nacional de Pesquisa de Monitoramento e Avaliação de Impacto Ambiental. Rodovia SP 340, Km 127,5. 13820-000, Jaguariúna, SP, Brasil. Tel.: (+5519) 3867-8700. Fax: (+5519) 3867-8740. E-mail: itamar@cnpma.embrapa.br 

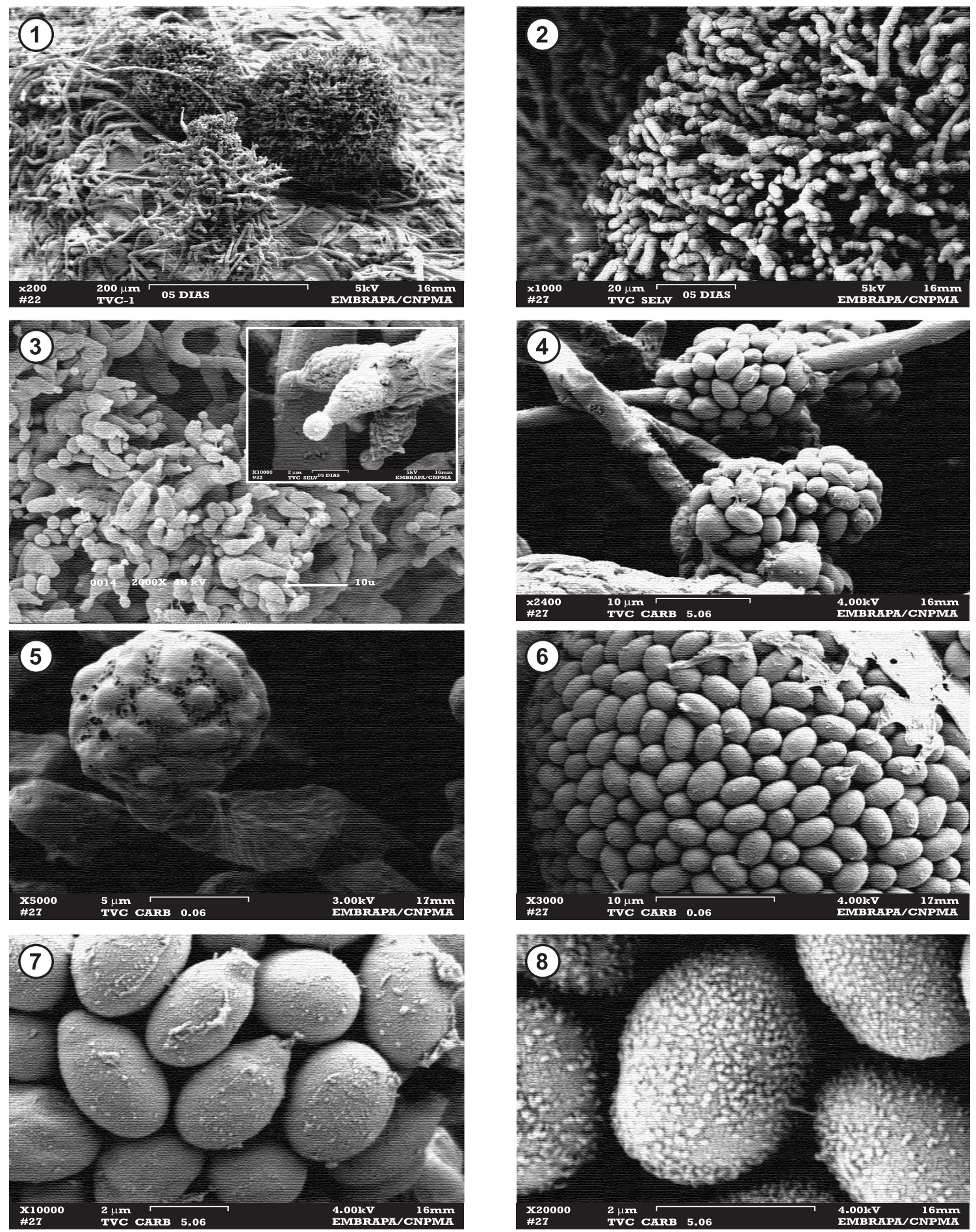

Figures 1 - 8. Scanning microscopy of fixed conidia and conidial masses of Trichoderma stromaticum. 1) Compact, velvetysurface conidiogenous pustules on ME after 6 days. 2) Pustules compact formed of vesicular or pseudoparenchymatous thinwalled $(4.0-4.5 \mathrm{~mm})$ wide cells arranged in chains that tend to branch dichotomously near the surface of the pustules. 3 ) Ampulliforme and sharphy constricted phialides. 4) Conidial balls developed from terminal phialides. 5) Conidial mass showing tight aggregation of conidia and presence of an extensive sheath surrounding the conidia. 6-7) Large conidia oblongs to ellipsoidal. 8) Phialospores which are verrucose at high magnification. 


\section{RESULTS AND DISCUSSION}

Fine structure of conidial surfaces and conidial en masses on a phialide was observable by means of a field emission scanning electron microscope.

Conidial surface morphology of Trichoderma stromaticum, although appeared to be smooth when viewed in light microscope they are roughened and verrucose (Fig. 8) when viewed in high magnification of $10.000 \mathrm{X}$, and more distinctly with increase of magnification of 20.000X.

This ornamentation type could not be reliably distinguished with light microscopy. Conidia broadly ellipsoidal to ovoid $(5.8 \mu \mathrm{m}-2.0 \mu \mathrm{m})$, presenting both ends broadly rounded or end rounded and the base narrowed or apiculate (Figs. 6 and 7). This variation existed even in a single conidial mass. Conidia are formed in compacted pustules (Fig. 1). The pustules are formed of wide cells arranged in chains that tend to branch dichotomously (Fig. 2). Thus, conidial en masses on phialides are observed (Fig. 4), with ampulliforme and sharp constricted phialides (Fig. 3). In some cases, it was common to observe conidia forming mucilaginous conidial head, that is, conidial mass showing tight aggregation of conidia and presence of extensive sheath surrounding the conidia, which is characteristic to the section Pachybasium (Fig. 5). These sheaths are also present in Trichoderma virens (8).

Phialospores of many species of Trichoderma are fastened slightly each other by means of epispore scars. T. viride, for example, is characterized by the rough-walled conidia in the microscope level (oil immersion). In T. longibrachiatum, the roughness of spore surface was pointed out under light microscopic level. At the electronmicroscopic level this roughness was due to intermittent partial thicknings of the outer wall of an epispore (7).

SEM has the potential to reveal previously unknown characters that could be helpful in species definition. This study reports on the features of the condial surfaces of T. stromaticum as useful morphological tools.

\section{RESUMO}

\section{Microscopia eletrônica de varredura de conídios de Trichoderma stromaticum, um agente de biocontrole da vassoura-de-bruxa do cacaueiro}

Estudos morfológicos de conídios de Trichoderma harzianun, um agente de biocontrole da vassoura-de-bruxa do cacaueiro, foram feitos sob microscopia eletrônica de varredura com emissão de campo. Características da superfície de conídios do fungo mostraram ser rugosas quando observadas em alta magnificação; fato esse impossível de ser visualizado por microscopia ótica. Também foram observados, com freqüência, massas de conídios completamente envolvidos por material mucilaginoso e detalhes de células ramificadas dicotomicamente que formam as pústulas.

Palavras chave: Controle biológico, cacau, Crinipellis perniciosa, morfologia de conídios

\section{REFERENCES}

1. Bissett, J. A revision of the genus Trichoderma L. Section Longibrachiatum Sect. nov. Canadian J. Botany, 62:924-931, 1984.

2. Brody, H.; Carbon, J. Electrophoretic karyotype of Aspergillus nidulans. Proc. Natl. Acad. Sci. USA., 86:6260-6263, 1989.

3. Cheng, C.; Tsrukagoshi, N.; Udaka, S. Transformation of Trichoderma viride using the Neurospora crassa pyr4 gene and its use the expression of a alfa-amylase A gene from Aspergillus oryzae. Curr. Genet., 18:453456, 1990 .

4. Chet, Y. Mycoparasitism - recognition, physiology and ecology. In New Directions in Biological Control; Alternatives for Suppressing Agricultural Pests and Diseases (UCLA Symposia on Molecular and Cellular Biology, New York: Alan R. Liss, 1990, pp.725-733.

5. Claydon, N.E.; Allan, M. Antifungal Alkyl Pyrones of Trichoderma harzianum. Transaction of the British Mycological Society, 88:503-513, 1987.

6. Domsch, K.H.; Gams, W.; Anderson, T.H. Trichoderma. In Compedium of Soil Fungi (ed. K.H. Domsch, W. Gams e T.H. Anderson), pp.794809. Academic Press: London, 1980.

7. Hashioka, Y. Scanning eletronmicroscopy on the mycoparasites, Trichoderma, Gliocladium and Acremonium. Rept. Toltori Mycol. Inst., 10:473-484, 1973.

8. Meyer, R.J.; Plaskowitz, J.S. Scanning electron microscopy of conidia and conidial matrix of Trichoderma. Mycologia, 8(2):312-317, 1989.

9. Nevalainen, H.; Penttilä, M.; Harkki, A.; Teeri, T.; Knowles, J. The molecular biology of Trichoderma and its application to the expression of both homologous and heterologous genes. In Molecular Industrial Mycology. System and Applications for Filamentous Fungi. Leon, S.A., and Berka, R.M. (eds.). New York: Marcel Dekker, 1991, pp.129148 .

10. Ricard, J.L.; Highley, T.L. Biocontrol of pathogenic fungi in wood and trees, with particular emphasis on the use of Trichoderma. Biocontrol News and Information, 9:133-142, 1988.

11. Ridout, C.J.; Coley-Smith, J.R.; Lynch, J.M. Enzyme activity and electrophoretic profile of extracellular protein induced by cell walls of Rhizoctonia solani. J. Gen. Microbiol., 132:2345-2352, 1986.

12. Rifai, M.A. A revision of the genus Trichoderma. Mycol. Papers., 116: 1-116, 1969.

13. Samuels, G.J.; Pardo-Schultheiss, R.; Hebbar, K.P.; Lumsden, R.D.; Bastos, C.N.; Costa, J.C.B.; Bezerra J.L. Trichoderma stromaticum sp. Nov., a parasite of the cacao witches' broom pathogen. Mycolog. Res., 104:760-764, 2000. 